Dig Surg 1997;14:466-467

\title{
EDS News EDS News
}

\section{Announcements}

Invitation to the

Second General Assembly of European Digestive Surgery

during the 6th UEGW in Birmingham, UK

Tuesday, October 21, 1997

5.30 p.m.

Hall 8, Level 5

International Convention Center (ICC)

Birmingham, UK

Invitation to the

EDS Symposium

The Cutting Edge in Coloproctology'

during the 6th UEGW in Birmingham, UK

presented by

J. Alexander-Williams, Birmingham, UK

Honorary President of EDS

and

N.S. Williams, London, UK

President of EDS

Agenda:

Development of EDS in 1996/97

Financial Report

Report of Activities of EDS and EDS-Committees

Relations with UEGF

Annual EDS Meeting

Election of the President 1999

Postgraduate courses 1998/99

Journal

Any other business

Wednesday Morning, October 22,1997

Session 37

International Convention Center (ICC)

Birmingham, UK

Program Overview

Progress in functional bowel disorders

The place of laparoscopic colorectal surgery

Total mesorectal excision or adjuvant therapy for rectal cancer

Problem solving in pouch surgery 
KARGER

E-Mail karger@,karger.ch Fax+41 613061234 http://www.karger.ch

(C) 1997 S.KargerAG, Basel

ÍWê $5 \frac{3}{8} 8 \mathrm{~W}^{3} / 4$

EDS Postgraduate Courses in 1997

Location Date Topic Organize

Bern, September Acute Pancreatitis.

Address

Transplantation Surgery

Switzerland 4-6,1997 New Concepts of Treatment F. HalterUniversity Hospital of Bern

CH-3010 Bern (Switzerland)

Phone:+41316322404

Fax: +41316329723

Barcelona, October Hepato-Biliary-Pancreatic L. Femandez-Cruz L. Fernandez-Cruz, M.D., Prof, of Surgery

Spain 13-15,1997 Surgery Head General and Gastrointestinal Surgery

University of Barcelona, Medical School Hospital Clinic, Víllarroel 170 E-08036 Barcelona

(Spain)

Phone: +34 32275400

, Fax: +34 32275454

Belgrade, November Cancer of the Cardia and I. Jekic Ivan M. Jekic, M.D.

Yugoslavia 1997 Stomach First Surgical Clinic, HBP Unit

Inst. for Digestive Diseases Clinical Centre of Serbia University of Belgrade Koste Todorovica

St. 611000 Belgrade (Yugoslavia)

Phone: 38111683856 Fax: 38111683978

Further information about these EDS postgraduate courses will be provided by the organisers to the EDS members.

All proposed EDS postgraduate course applications have to be sent to Prof. L. Fernandez-Cruz, Chairman of the Education and Training Committee, for further coordination and approval. It was proposed and seconded that the official language of all EDS postgraduate courses and meetings should be in English. In cases where the official language of the EDS postgraduate course could not be in English, a simultaneous translation into English should be provided to allow all EDS members to participate actively. The proposal was accepted unanimously by the Assembly.

EDS Members (July 1997)

Countries

Total i

Countries

Total |

[ Countries

Total

Algeria

1

India

2 


South Africa
1
Austria
3
Iraq
22
South Korea
1
Belgium
3
Israel
4
Spain
4
Canada
1
Italy
42

Sweden

17

Chile

3

Japan

1

Switzerland

106

China

20

Latvia

1

Syria

2

Croatia

1

Lebanon

1

The Netherlands

11

Cyprus

1

Lithuania

40

Turkey

12

Czech Republic

6 


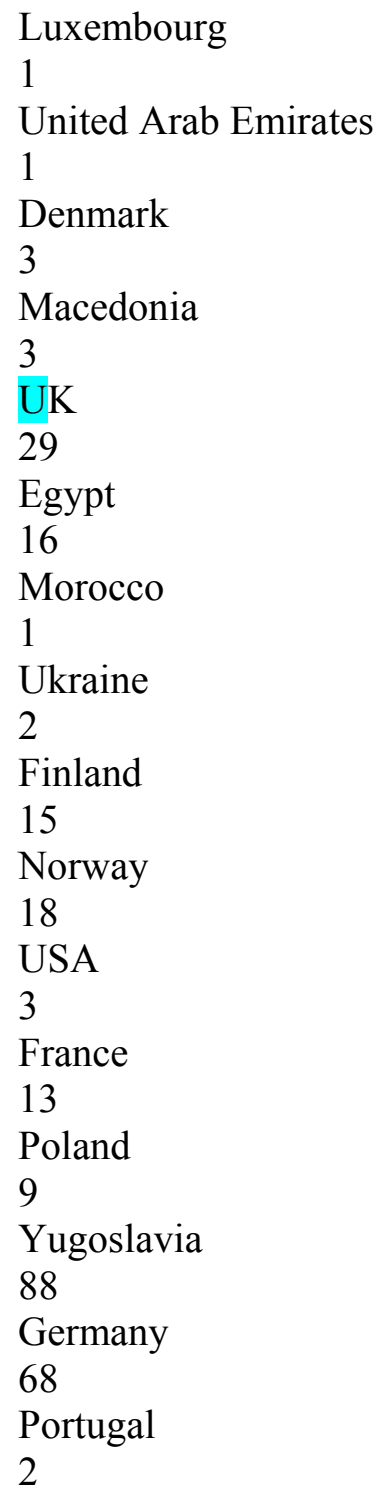


1 Total

1 EDS News

467 